16 Kessler RC, Ustun TB. The World Mental Health (WMH) Survey Initiative Version of the World Health Organization (WHO) Composite International Diagnostic Interview (CIDI). Int J Methods Psychiatr Res 2004; 13: 93-121.

17 Turner CF, Ku L, Rogers SM, Lindberg LD, Pleck JH, Sonenstein FL. Adolescent sexual behaviour, drug use, and violence: increased reporting with computer survey technology. Science 1998; 280: 867-73.

18 First MB, Spitzer RL, Gibbon M, Williams JBW. Structured Clinical Interview for DSM-IV-TR Axis I Disorders, Research Version, Non-Patient Edition (SCID-I/ NP). Biometrics Research, New York State Psychiatric Institute, 2002.

19 Kessler RC, Berglund P, Demler O, Jin R, Walters EE. Lifetime prevalence and age-of-onset distributions of DSM-IV disorders in the National Comorbidity Survey Replication. Arch Gen Psychiatry 2005; 62: 593-602.

20 Haro JM, Arbabzadeh-Bouchez S, Brugha TS, de Girolamo G, Guyer ME, Jin R, Lepine JP, Mazzi F, Reneses B, Vilagut G, Sampson NA, Kessler RC. Concordance of the Composite International Diagnostic Interview Version 3.0 (CIDI 3.0) with standardized clinical assessments in the WHO World Mental Health Surveys. Int J Methods Psychiatr Res 2006; 15: 167-180.

21 Efron B. Logistic regression, survival analysis, and the Kaplan Meier curve. $J$ Am Sociol Assoc 1988; 83: 414-25.

22 Wolter K. Introduction to Variance Estimation. Springer-Verlag, 1985.

23 SUDAAN: Professional Software for Survey Data Analysis computer program. 8.0.1 Version. Research Triangle Institute, 2002.

24 Eddleston M, Konradsen F. Commentary: time for a re-assessment of the incidence of intentional and unintentional injury in India and South East Asia. Int J Epidemiol 2007; 36: 208-11.
25 Brewin CR, Andrews B, Gotlib IH. Psychopathology and early experience: a reappraisal of retrospective reports. Psychol Bull 1993; 113: 82-98.

26 Hardt J, Rutter M. Validity of adult retrospective reports of adverse childhood experiences: review of the evidence. J Child Psychol Psychiatry 2004; 45: 260-73.

27 Schlesselman JJ. Case-Control Studies: Design, Conduct, and Analysis Oxford University Press, 1982.

28 Kendler KS, Gallagher TJ, Abelson JM, Kessler RC. Lifetime prevalence, demographic risk factors, and diagnostic validity of nonaffective psychosis as assessed in a US community sample. The National Comorbidity Survey. Arch Gen Psychiatry 1996; 53: 1022-31.

29 Phillips MR, Yang G, Li S, Li Y. Suicide and the unique prevalence pattern of schizophrenia in mainland China: a retrospective observational study. Lancet 2004; 364: 1062-8.

30 Cavanagh JT, Carson AJ, Sharpe M, Lawrie SM. Psychological autopsy studies of suicide: a systematic review. Psychol Med 2003; 33: 395-405.

31 Mann JJ, Waternaux C, Haas GL, Malone KM. Toward a clinical model of suicidal behaviour in psychiatric patients. Am J Psychiatry 1999; 156: 181-9.

32 Crawford MJ, Thomas O, Khan N, Kulinskaya E. Psychosocial interventions following self-harm: systematic review of their efficacy in preventing suicide. Br J Psychiatry 2007; 190: 11-7.

क EXTRA

\title{
Word pictures of depression: anhedonia
} Sharon Mcconville

I have never been a particularly hedonistic type of person, but for me, the following illustration is useful in summing up my experience of anhedonia:

'The sun is shining brilliantly and the sky is a cloudless azure. Everything looks pristine. The trees and bushes appear velvety, like model vegetation on a model railway set, and the lines of the buildings are sharp like the edges of neatly-wrapped parcels. My friends are excited because they have planned to watch a movie which is being projected on to the cliff face at Cavehill, and it is a perfect evening for such an adventure. I have a ticket but I have decided not to go. It is cloudy and dark in my inner world and I do not have the energy left to construct a bridge which I can cross into this bright parallel reality. Sometimes I can do it; sometimes I can mentally detach myself from the gloom and live for a time in the glow created by the people around me, like a candle which does not quite smoulder out because it is relit using the flame of others which burn more strongly. This is an excursion which I would ordinarily enjoy: the film is one which I would like to see; the people are friends with whom I am comfortable; I would like to be outside in a beautiful setting with panoramic views; and the novelty value of marrying Hollywood commercialism with the stark majesty of nature appeals to me. Tonight, I know that I could not concentrate on any film; I am intimidated by the thought of having to interact with a number of different people, taking into account their different needs and the differing expectations which they have of me; and I crave silence and space unmarred by noisy crowds.' 